\title{
PENGKHOTBAH DAN PERANAN ROH KUDUS DALAM BERKHOTBAH
}

\section{Oleh: Sunarto}

\begin{abstract}
ABSTRAK
Gagasan berkhotbah pertama kali muncul bukan dimulai dari manusia, tetapi dimulai dari hati Allah sendiri. Sejak manusia yang pertama diciptakan oleh Allah, hakikat berkhotbah sudah dikerjakan oleh Allah, demikian juga ketika manusia jatuh ke dalam dosa, Allah langsung menyampaikan berita firman-Nya kepada manusia. Mandat berkhotbah akhirnya diteruskan kepada para nabi, rasul dan semua orang percaya dipanggil untuk menyampaikan kebenaran dari Allah. Dunia yang gelap oleh dosa memerlukan terang kebenaran supaya mengerti akan kehendak Allah. Berkhotbah salah satu instrumen yang dapat dipakai oleh Allah untuk menyatakan kehendak-Nya bagi manusia yang berdosa. Dalam berkhotbah ada dua aspek yang terlibat, yaitu: unsur ilahi dan insani. Ada peranan Roh Kudus dalam berkhotbah dan ada peranan manusia yang dipakai oleh Allah dalam menyampaikan kehendak-Nya.

\section{Frasa Kunci: Berkhotbah, pengkhotbah, panggilan pengkhotbah, peran Roh Kudus.}

\section{PENDAHULUAN}

Salah satu unsur penting dalam kegiatan ibadah Kristen adalah berkhotbah atau pemberitaaan firman Tuhan. Anggapan begitu pentingnya berkhotbah, bahkan bisa menempatkan orang Kristen dengan memerhatikan siapa yang akan berkhotbah pada hari minggu ini atau jadwal khotbah untuk minggu depan. Jadwal berkhotbah yang ditulis dalam warta, bahkan bisa menentukan sesorang untuk datang ke gereja atau tidak, kehadirannya bisa dipengaruhi siapa yang berkhotbah pada minggu itu.

Sikap tersebut tentunya tidak dapat dibenarkan karena orang datang ke gereja bukan didasari karena mau bersekutu dengan Allah 


\section{2| PENDIDIKAN KRISTEN YANG MENCERAHKAN}

dan jemaat-Nya, tetapi ke gereja ditentukan oleh siapa yang berkhotbah. Kehadirannya ke gereja bertumpu pada pribadi seorang pengkhotbah, bukan kepada Allah yang bisa memakai siapa yang dikehendakinya. Ibadah yang hidup bukan hanya ditentukan oleh khotbah, karena unsur berkhotbah tidak bisa berdiri sendiri karena berkaitan dengan bagian tata liturgi yang lain, tetapi sayangnya sebagian jemaat berpusat pada pelayanan berkhotbah.

Terlepas dari sikap yang tidak tepat dalam menghadiri kegiatan ibadah yang dilakukan oleh sebagian jemaat, siapa pun yang mendapatkan jadwal berkhotbah harus menyiapkan diri sebelum berkhotbah. Begitu pentingnya persiapan khotbah, bahkan sebagian pengkhotbah berani menolak ketika diminta berkhotbah secara mendadak. Namun disisi yang lain, ada sebagian berpendapat bahwa materi berkhotbah tidak perlu dipersiapkan sebelumnya, karena mereka percaya kalau Roh Kudus akan menolong hambanya pada waktu naik mimbar. Walaupun tanpa persiapan mereka percaya kalau Roh Kudus akan memberikan tuntunan pada waktu sesorang menyampaikan khotbahnya.

Mengapa orang percaya harus berkhotbah? Kualifikasi yang bagaimanakah yang harus dipenuhi seorang pengkhotbah? Haruskah seorang pengkhotbah memersiapkan diri sebelum menyampaikan materi khotbah di depan jemaat? Apakah persiapan materi khotbah memberi pengaruh yang besar saat menyampaikan khotbah? Apakah struktur khotbah memberi pengaruh bagi kemudahan pendengar dalam mendengarkan khotbah? Bagaimanakah peranan Roh Kudus memimpin para pengkhotbah dalam menyampaikan berita khotbah?

\section{DASAR TEOLOGIS PANGGILAN BERKHOTBAH}

\section{Panggilan Berkhotbah Dimulai dari Hati Allah}

Hakikat berkhotbah adalah ilmu dan seni menyampaikan berita kepada orang lain. Secara teologis panggilan berkhotbah pertama kali dimulai dari pribadi Allah sendiri ketika menciptakan manusia dan ditempatkan di taman Eden. Kitab Kejadian 1:28-30 merecam khotbah Allah demikian menulis: 
28 Allah memberkati mereka, lalu Allah berfirman kepada mereka: "Beranakcuculah dan bertambah banyak; penuhilah bumi dan taklukkanlah itu, berkuasalah atas ikan-ikan di laut dan burungburung di udara dan atas segala binatang yang merayap di bumi." 29 Berfirmanlah Allah: "Lihatlah, Aku memberikan kepadamu segala tumbuh-tumbuhan yang berbiji di seluruh bumi dan segala pohonpohonan yang buahnya berbiji; itulah akan menjadi makananmu. 30 Tetapi kepada segala binatang di bumi dan segala burung di udara dan segala yang merayap di bumi, yang bernyawa, Kuberikan segala tumbuh-tumbuhan hijau menjadi makanannya." Dan jadilah demikian."

Setelah manusia ditempatkan di Taman Eden dan memberikan semua aturan yang harus ditaati, tetapi ternyata manusia melanggar ketetapan hukum Allah. "Tidak lama kemudian kemudian segala sesuatu menjadi rusak oleh dosa manusia. Sejak saat itu, Allah berkarya untuk mendirikan kembali Kerajaan-Nya dan untuk memanggil umat manusia kembali bersekutu dengan-Nya."1

Akibat pelanggaran itu manusia jatuh ke dalam dosa. Allah lalu menyampaikan khotbah kepada manusia demikian:

9 Tetapi TUHAN Allah memanggil manusia itu dan berfirman kepadanya: "Di manakah engkau?"10 Ia menjawab: "Ketika aku mendengar, bahwa Engkau ada dalam taman ini, aku menjadi takut, karena aku telanjang; sebab itu aku bersembunyi."11 firman-Nya: "Siapakah yang memberitahukan kepadamu, bahwa engkau telanjang? Apakah engkau makan dari buah pohon, yang Kularang engkau makan itu? ..."

Maka jelaslah siapakah yang pertama kali menggunakan khotbah tidak lain adalah pribadi Allah sendiri. Allah berkhotbah bukan hanya kepada Adam dan Hawa, tetapi kepada setiap orang yang mendapatkan kepercayaan dari kehendak-Nya, ketika Allah

${ }^{1}$ Vaughan Roberts, Gambar Besar dari Allah, Menelusuri Alur cerita Alkitab (Jakarta: Literatur Perkantas, 2014), 40. 
berkehendak mau berbicara dengan seseorang. Mengapa orang percaya harus berkhotbah karena mandat ini diberikan kepada manusia sebagai instrumen untuk menyampaikan berita dari Allah.

\section{Allah Memanggil Nabi-nabi untuk Menyampaikan Khotbah}

Jauh sebelum khotbah disampaikan dimimbar-mimbar gereja, Allah sudah sejak lama memanggil para nabi untuk menyampaikan warta kebenaran-Nya. Para nabi dipanggil untuk menjadi corong Allah, karena hakikat dari pemanggilan pelayanan nabi adalah menjadi penyambung lidah Allah. Nabi-nabi berkata-kata bukan atas kesenangannya pribadi, tetapi mereka menyampaikan apa menjadi kehendak Allah bagi umat-Nya. Demikian dikatakan dalam Keluaran 5:1 "Kemudian Musa dan Harun pergi menghadap Firaun, lalu berkata kepadanya: "Beginilah firman TUHAN, Allah Israel: Biarkanlah umat-Ku pergi untuk mengadakan perayaan bagi-Ku di padang gurun."

Pada era kerajaan Israel kehendak Allah untuk menyampaikan khotbah kepada umat-Nya juga diteruskan dengan memanggil para nabi pada zaman itu. Ketika Saul diangkat untuk menjadi raja Israel dan memimpin bangsa ini, Allah memakai Samuel untuk mendampingi umatNya. Samuel pula yang dipakai oleh Allah untuk menyatakan kehendak-Nya supaya bangsa Israel hidup berkenan pada Allah. Ketika Saul sang pemimpin mulai menyimpang dari kehendak Allah, Allah memakai Samuel untuk menegor Saul, bahwa apa yang dilakukan telah menyimpang dari kehendak Allah.

Allah memilih para pengkhotbah, Ia memilih Ezra untuk berdiri lebih tinggi dari orang banyak dan membuka firman (Nehemia 8:5). Ia meletakkan firman di dalam mulut para nabi (Yer. 1:9). ${ }^{2}$ Maka jelaslah mengapa orang percaya harus berkhotbah karena mandat berkhotbah diberikan kepada para nabi untuk menyampaikan warta kebenaran dari Allah. Mandat berkhotbah tersebut hakikatnya juga diberikan kepada semua pengkhotbah pada masa kini.

${ }^{2}$ Kenton C. Anderson, Choosing to Preach (Malang: Gandum Mas, 2010), 29. 


\section{Yesus Memanggil Para Rasul untuk Menyampaikan Kabar Baik (Injil)}

Puncak khotbah Allah pada akhirnya diteruskan dengan memilih anak-Nya yang tunggal untuk datang ke dunia dan melanjutkan dengan pelayanan berkhotbah. "Itulah mengapa Aku telah diutus," kata Yesus (Markus 1:38). Karya Yesus dalam menyelamatkan orang berdosa pertama diberitakan oleh Yesus sendiri secara langsung. Yesus berkeliling memasuki kota dan desa untuk berkhotbah dan mengajar. Selanjutnya mandat berkhotbah diteruskan kepada para murid yang kelak menjadi penerus dalam menyampaikan kabar baik atau Injil.

Selama pelayanannya di dunia Yesus memersiapkan para murid yang kelak lebih dikenal sebagai para rasul untuk meneruskan tugas pelayanan di dunia ini. Yesus mengajar dan memerlengkapi mereka supaya bisa menjadi pengkhotbah-pengkhotbah dalam menyampaikan kabar kebenaran dari Allah. Sebelum Yesus naik ke sorga perintah untuk menyampaikan berita Injil diberikan kepada para rasul, yang hakikatnya juga diperintahkan kepada setiap orang percaya yang hidup pada masa kini. Ketika saatnya untuk mendirikan gereja mula-mula, Allah memanggil Petrus, dan ribuan orang menjadi bagian dari tubuh Kristus melalui khotbahnya (Kisah. 2:41). ${ }^{3}$

Melalui para rasul akhirnya gereja berkembang dan menyebar ke berbagai daerah. Dari bumi Palestina, Injil menyebar ke Asia Kecil selanjutnya menyebar ke benua Eropa. Perkembangan Injil bukan hanya melebar ke Eropa, tetapi juga menyebar ke Afrika dan ke wilayah timur, yaitu Asia. Secara tradisi gereja percaya bahwa rasul Tomas pergi sampai ke tanah India untuk menjadi pengkhotbah di wilayah itu. Kini pelayanan berkhotbah harus diteruskan oleh semua orang percaya untuk mewartakan kasih Tuhan di berbagai tempat di muka bumi ini.

3Ibid, 29. 


\section{Allah memanggil setiap orang percaya untuk menyampaikan kebenaran}

Panggilan untuk menjadi pengkhotbah bukan hanya dikhususkan untuk para rasul, para gembala dan penatua, tetapi pada dasarnya setiap orang percaya juga dipanggil untuk menjadi seorang pengkhotbah. Amanat agung dalam Matius 28:19-20 hakikatnya ditujukan kepada setiap orang percaya yang sudah menerima Yesus sebagai Tuhan dan Juruselamat juga dipanggil untuk menjadi pengkhotbah bagi sesamanya. Sekalipun dalam konteks masa kini sebagian gereja hanya memberikan kesempatan atau mengizinkan bahwa berkhotbah itu kebanyakan hanya di dominasi oleh para pendeta, tetapi sebagian gereja yang lain juga mengizinkan para pengkhotbahnya berasal dari anggota jemaat biasa yang tidak duduk dalam struktur lembaga gereja.

Menyampaikan firman Tuhan atau berkhotbah hakikatnya bukan hanya dibatasi di gedung gereja, yaitu berkhotbah pada hari Minggu. Khotbah bisa disampaikan dalam kelompok-kelompok kecil di rumah, kelompok belajar tingkat sekolah menengah, atau persekutuan mahasiswa. Penggalian Alkitab dalam kelompok rumah tangga yang dipimpin oleh jemaat biasa (bukan penatua sekalipun) lebih banyak memberi kesempatan bagi orang Kristen untuk belajar secara langung dari Alkitab. Kelompok seperti ini juga memberi kesempatan pertumbuhan menuju kedewasaan rohani bagi anggotanya dan membagikan Injil kepada anggota keluarga, teman, dan para tetangga. ${ }^{4}$

\section{KUALIFIKASI YANG HARUS DIMILIKI OLEH PENGKHOBAH}

Berkhotbah adalah tugas yang mulia dan penting, itu sebabnya menjadi seorang pengkhotbah harus memenuhi persyaratan. Persyaratan bagi seorang pengkhotbah tidak hanya memenuhi kemampuan intelektual saja. Persyaratan utama adalah kehidupan rohani, moral dan kepribadiannya. Kualifikasi seperti ini lebih

${ }^{4}$ Catharine Padilla dkk, Memahami dan Berbagi firman Tuhan (Jakarta: Yayasan Pancar Pijar Alkitab, 2009), 95. 
penting dari pada kemampuan pengkhotbah yang hanya pandai dalam beretorika. Para pendengar bukan hanya memerhatikan apa yang diucapkan seorang pengkhotbah, mereka juga memerhatikan apakah yang diucapkan sesuai dengan kelakuannya. Kehidupan seorang pengkhotbah seharusnya satu kata dan satu perbuatan. Khotbah yang baik belum tentu menempatkan hati jemaat untuk menerima dengan sukacita, mereka bisa tersandung dengan seorang pengkhotbah karena apa diucapkan tidak selaras dalam kehidupannya. Berikut kualifiksi yang harus dipenuhi bagi seorang pengkhotbah supaya bisa dipakai oleh Tuhan dalam pelayanannya, yaitu:

\section{Orang yang Sudah Bertobat di Dalam Kristus}

"Kamu harus dilahirkan kembali" (Yohanes 3:7). Kelahiran kembali atau lahir baru memang berlaku bagi semua orang percaya, terlebih bagi seorang pengkhotbah. Syarat ini mutlak diperlukan bagi seorang pengkhotbah, karena tidak mungkin seseorang bisa menuntun orang lain supaya bertumbuh di dalam Tuhan kalau pengkhotbahnya belum ada di dalam Kristus. Seorang pengkhotbah harus sudah mengalami pertobatan lebih dulu, sebelum mereka melayani orang lain.

Keharusan untuk dilahirkan kembali ditetapkan oleh Tuhan Yesus sendiri sebagai syarat untuk memasuki Kerajaan Allah (Yohanes 3:1-6). Orang itu harus sudah dilahirkan kembali, sebab jika tidak, ia sendiri sebenarnya tidak dapat melihat Kerajaan Allah. Syarat ini paling utama, paling unggul, dari segi kepentingan, bagi para pengkhotbah. Ketika seseorang sudah mengalami kelahiran baru pada akhirnya akan mengalami pertobatan di dalam Kristus.

Melalui kelahiran kembali Roh Kudus memulai kehidupan yang baru di dalam hati orang yang berdosa. Kelahiran kembali semata-mata dimulai oleh Allah melalui karya Roh Kudus (Yohanes 1:13; 3:5-6; 1 Petrus 1:3, 23). Kelahiran kembali bukan hasil karya manusia, tetapi karunia kepada semua orang yang dipilih oleh Allah. 
Apabila dalam kelahiran kembali yang menjadi aktor utama adalah Roh Kudus, sedangkan dalam pertobatan memerlukan kerja sama dari manusia untuk mau berubah dari segala kejahatan. Pertobatan berarti perubahan total manusia terhadap segala dosa dan keburukannya, dan berpaling kepada Yesus Kristus sebagai juru selamat. ${ }^{5}$

\section{Orang yang Mengasihi Allah dan Sesama}

Seorang pengkhotbah pasti sering berkhotbah dan sering berbicara tentang tema mengasihi Allah. Pengkhotbah yang juga sebagai orang percaya pada dasarnya masih berjuang untuk taat pada perintah "kasihilah Tuhan Allah dengan sepenuhnya". Perintah kasih menjadi standar untuk pengkhotbah dan jemaat. Jika pengkhotbah memiliki jabatan sebagai gembala sidang, karena posisi ini merupakan panggilan khusus, gembala sidang dituntut untuk mempunyai hubungan kasih dengan Tuhan serta standard kepadaNya dari hari demi hari. Kasih yang dituntut bagi seorang pengkhotbah adalah kasih yang semaksimal mungkin (Baca: Markus 12:30-31).

Kasih yang dituntut bagi seorang pengkhotbah adalah kasih yang semaksimal mungkin (Markus 12:30-31). Berikut yang menolong pengkhotbah untuk mengevaluasi apakah kasihnya terhadap Allah sudah berkenan, yaitu:

Pertama, mengasihi Allah dengan segenap hati. "Hati" adalah bagian dari manusia yang berkaitan dengan masalah kerelaan dan emosi. Konsep ini begitu penting sehingga hal yang berkaitan dengan hati disebutkan lebih dari 1.000 kali dalam Alkitab. Mengasihi Allah dengan segenap hati berarti seorang pengkhotbah harus mengasihi Allah dengan penuh ketulusan.

Kedua, mengasihi Allah dengan segenap jiwa. Biasanya jiwa dianggap sebagai pusat pikiran, ketentuan, dan semua bagian hidu.p

${ }^{5}$ Gerrit Riemer dkk, Berteologi Abad XXI Menjadi Kristen Indonesia Di Tengah Masyarakat Majemuk (Jakarta: Perkantas, 2015), 611, 620, 621. 
yang tidak kelihatan. Untuk mengasihi Tuhan dengan segenap jiwa, dituntut penyerahan secara total dari Pengkhotbah terhadap Allah.

Ketiga, mengasihi Allah dengan segenal akal budi. Akal budi menyatakan semua potensi daya nalar yang diberikan dari Allah kepada seseorang. Mengasihi Allah dengan segenap akal budi berarti semua potensi daya nalar yang dimiliki seseorang pengkhotbah harus dipersembahkan untuk Allah.

Keempat, mengasihi Allah dengan segenap kekuatan. Mengasihi Allah dengan segenap kekuatan artinya seorang pengkhotbah yang akan menyampaikan firman Tuhan harus memersiapkan bahan khotbah dengan sebaik-baiknya. Persiapan yang dilakukan bukan dengan waktu ala kadarnya, tetapi materi khotbah yang disiapkan dengan sebaik-baiknya.

Pengkhotbah harus mengasihi jemaatnya Pengkhotbah yang mengasihi jemaatnya sudah atau pasti akan mendapat kepercayaan dari mereka. Jadi, apa yang dibicarakan juga diterima sebab jemaat merasa dikasihi. Dengan demikian seorang pengkhotbah dapat mengkhotbahkan semua pokok Alkitab, baik yang mudah untuk diterima maupun yang sukar diterima, karena maksudnya tidak dicurigai jemaat yang menerima pesan itu.

\section{Mengerti Prinsip-prinsip Hermeneutika Alkitab}

Pengkhotbah harus bertanggung jawab di hadapan Tuhan dan sesama, karena itu seorang pengkhotbah harus menguasai prinsipprisip dasar penafsiran Alkitab. Hermeneutika adalah "ilmu yang menjelaskan secara tepat prinsip-prinsip atau metode-metode untuk menafsir makna yang dimaksud seorang penulis."' Hermeneutika penting karena hermeneutika memampukan seseorang untuk beralih dari teks kepada konteks, mengizinkan makna yang diinspirasikan

${ }^{6}$ Grant R. Osborne, The Hermeneutical Spiral: A Comprehensive Introduction to Biblical Interpretation (Surabaya: Momentum, 2012), 1. 
Allah dari firman itu untuk berbicara pada hari ini dengan kesegaran dan kekuatan yang sama seperti sebelumnya sesuai dengan latar belakang aslinya. ${ }^{7}$

Seorang yang hendak belajar berkhotbah adalah orang yang mau belajar ilmu tafsir Alkitab. Pengkhotbah yang menafsirkan Alkitab dengan tidak memerhatikan kaidah-kaidah penafsiran Alkitab adalah orang yang berbahaya. Mengapa? karena orang-orang yang mendengarkan khotbahnya akan menuruti apa yang disampaikannya, jika tafsirannya benar maka akan berdampak yang baik bagi pendengar, tetapi jika itu salah, hal ini dapat menyesatkan. Ajaran-ajaran sesat bisa muncul karena mereka menafsirkan Alkitab menurut pengertiannya sendiri.

\section{Mempunyai Landasan Teologi yang Kuat}

Rahasia berkhotbah bukan hanya terletak pada penguasaan teknik-teknik tertentu, tetapi juga dipengaruhi oleh keyakinankeyakinan tertentu. Dengan kata lain, pemahaman teologi lebih penting daripada metodologi. Tentu saja prinsip-prinsip berkhotbah juga perlu dipelajari dan keterampilan perlu dikembangkan. Tehnik berkhotbah dapat menjadikan seseorang menjadi orator, namun jika seseorang ingin menjadi pengkhotbah, pemahaman teologi yang benar sangat dibutuhkan. Meskipun pemahaman teologi pengkhotbah bisa subyektif karena dipengaruhi oleh seorang teolog sebelumnya, tetapi apabila ia menafsirkan Alkitab dengan jujur, tanpa prasangka dan manipulasi serta menerapkan sarana hermeneutika yang ketat pasti menghasilkan pemberitaan firman yang bertanggung jawab.

Jika teologi seorang pengkhotbah benar akan menjadi dasar pemahaman bagi yang mendengarkan dan berakibat pula pada perilaku yang benar bagi jemaat yang mendengarkannya. Kebutuhan utama akan khotbah yang bermutu atau khotbah yang alkitabiah dan demi kebaikan gereja, para pengkhotbah harus mempunyai landasan

${ }^{7}$ Ibid, 3. 
teologi yang kuat. ${ }^{8}$ Berikut keyakinan-keyakinan teologis yang perlu dikuasai seorang pengkhotbah dengan baik, seperti: pemahaman doktrin Allah yang benar, keyakinan Alkitab adalah wahyu Allah, pemahaman doktrin keselamatan yang benar, pemahaman doktrin gereja yang benar, dan semua doktrin iman Kristen yang berakar dari Alkitab.

\section{Mempunyai Keterampilan dalam Bidang Komunikasi.}

Berkhotbah sebagai sebuah ilmu bukan hanya sekedar berani untuk berbicara di depan umum, tetapi seorang pengkhotbah juga membutuhkan sebuah keahlian dari pelayanan itu. Keterampilan yang harus dimiliki oleh seorang pengkhotbah adalah penguasaan ilmu komunikasi. Ilmu komunikasi adalah ilmu yang mempelajari tentang tata cara beromunikasi serta menggunakan berbagai alat komunikasi sebagai sarana komunikasi terhadap masyarakat. Adapun definisi ilmu komunikasi yang lain yaitu ilmu yang mempelajari caracara untuk mentransfer ide dari satu individu atau grup ke individu ataupun ke grup yang lainnya. Proses transfer itu sendiri dapat melalui media tertulis, lisan, maupun media yang lainnya. ${ }^{?}$

Ada tiga unsur utama dalam khotbah yang saling berpengaruh yaitu: penafsiran, pesan dan komunikasi. Pengkhotbah sebagai seorang komunikator harus terus memikirkan apa yang dapat meningkatkan keefektifan komunikasi kepada para pendengar. ${ }^{10}$ Menggabungkan berbagai pendekatan melalui berbagai media antara komunikasi lisan, tertulis, dan gambar, bisa menjadi alat yang ampuh bagi pengkhotbah dalam memberitakan firman Tuhan.

${ }^{8}$ John Stott dan Greg Schart, Tantangan dalam Berkhotbah (Jakarta: Yayasan Bina Kasih, 2013), 33.

9 Pengertianku.net, "Pengertian Apa pun" Di unduh tanggal 29 Februari 2016.

${ }^{10}$ Hasan Sutanto, Homiletik, Prinsip dan Metode Berkhotbah (Malang: Literatur SAAT, 2007), 190. 
Aspek bidang komunikasi tidak boleh diabaikan oleh pengkhotbah karena aspek ini juga terkait dengan gaya atau pola penyampaikan materi khotbah. Dalam ilmu komunikasi pengkhotbah bukan hanya menggunakan suara, teks dan gambar, tetapi bisa menggunakan komunikasi nonverbal. Penggunaan suara yang baik disertai dengan gerakan anggota tubuh serta kontak mata yang tepat akan menambah kekuatan dan kualitas suatu khotbah.

\section{STRUKTUR BERKHOTBAH}

Pada dasarnya tidak ada yang disebut satu-satunya bentuk khotbah. Jika seseorang menggunakan teknik tanya jawab, cerita, obyek pelajaran dapat membantu orang percaya memuliakan dan melayani para pendengar, seseorang harus berkhotbah secara bebas dengan sebuah variasi dari bentuk-bentuk sebagaimana yang dilakukan Yesus dan para pengkhotbah yang dicatat dalam Alkitab.

Sejumlah orang percaya dalam berkhotbah ditandai dengan sebuah bentuk tertentu, misalnya sebuah khotbah harus memiliki sejumlah poin, misalnya dua poin dan tiga pion, sedangkan bagi yang lain, sebuah khotbah harus mengikuti teks ayat per ayat, bagi yang lain lagi, sebuah khotbah harus diakhiri dengan sebuah undangan. ${ }^{11}$ Sekalipun tidak ada satu bentuk khotbah yang baku, namun bukan berarti sebuah khotbah disampaikan tanpa format atau bentuk yang tidak jelas.

Khotbah sebaiknya menggunakan struktur yang baik. Struktur khotbah berkaitan dengan cara sesuatu disusun atau dibangun. Ibarat seperti membangun rumah memerlukan pondasi, tembok, pintu, jendela sampai dengan atapnya. Tanpa struktur yang logis dan jelas, suatu khotbah tidak akan berpengaruh dan berkuatan sebagaimana mestinya. Bahkan tidak menutup kemungkinan tanpa struktur khotbah yang baik dapat menimbulkan kebingungan pendengar.

${ }^{11} \mathrm{Jeffrey}$ D. Arthurs, Preaching with Variety (Malang: Literatur SAAT, 2012), 15-16. 
Untuk menghindari kebingungan tersebut, pengkhotbah harus memahami dan memerlukan struktur khotbah yang baik. ${ }^{12}$

Kitab-kitab yang ada di Alkitab ditulis dalam konteks budaya manusia yang sedang berkembang pada zamannya. Dari segi kesusasteraan teks-teks kitab Suci ditulis juga menggunakan bentuk sastra yang berkembang pada zamannya. Maka dilihat dari muatan isi pesannya setiap teks menggunakan susunan, misalnya ada bagian pendahuluan, pesan utama dan bagian penutup. Tugas seorang pengkhotbah adalah bagaimana menemukan pesan utama dari sebuah teks dan maknanya bagi pendengar di era sekarang.

Maka khotbah yang benar dan berkualitas adalah khotbah yang alkitabiah. Khotbah alkitabiah adalah khotbah yang menempatkan Alkitab pada pusatnya, khotbah yang menyingkapkan kekuatan dan kekuasaan Alkitab. Sekalipun seorang pengkhotbah itu mengkhotbahkan tentang topik atau tema tertentu. Khotbah yang alkitabiah adalah khotbah yang menguraikan suatu perikop Alkitab. ${ }^{13}$ Apa pun tema yang mau dibahas dan disampaikan kepada pendengar, sebuah khotbah yang disusun dengan menggunakan sebuah struktur akan menolong para pendengar untuk memahaminya.

Dalam ilmu homiletika ada berbagai jenis khotbah yang banyak dikembangkan oleh seorang pengkhotbah dalam menyampaikan kebenaran firman Tuhan: Pertama, Khotbah Topikal, suatu khotbah yang bagian-bagian utamanya diambil dari topiknya atau pokoknya, lepas dari teks. Khotbah topikal adalah sebuah khotbah yang bertumpu dan bertitik tolak dari topik. Biasanya berkisar pada sebuah pokok yang diambil dari dalam atau luar Alkitab.

12Jeerry Vines dan Jim Shaddix, Homiletika, Kuasa dalam Berkhotbah (Malang: Gandum Mas, 2009), 203-204

${ }^{13}$ Jonathan Lamb dkk, Memahami dan Berbagi firman Tuhan, 186. 
Kedua, Khotbah Tekstual, adalah suatu khotbah yang bagian-bagian utamanya diperoleh dari satu teks yang terdiri atas suatu bagian Alkitab yang pendek. Setiap bagian dipakai sebagai suatu garis besar dan teks memberikan tema khotbah itu.

Ketiga, Khotbah Ekspositori bisa juga disebut khotbah eksposisi karena menerangkan lebih dari dua ayat, atau satu perikop, satu pasal, dan atau bahkan satu kitab/surat; apakah itu kitab yang pendek langsung dikhotbahkan, atau kitab yang panjang yang dikhotbahkan secara seri. Menurut Haddon Robinson khotbah ekspositori dapat didefinisikan sebagai berikut:

Khotbah yang mengkomunikasikan suatu konsep alkitabiah, yang diperoleh dari dan disampaikan melalui penyelidikan historis, gramatikal, dan kesusasteraan suatu teks di dalam konteksnya, di mana Roh Kudus pertama-tama menerapkannya kepada kepribadian dan pengalaman pengkhotbah kemudian melalui pengkhotbah, menerapkannya kepada para pendengar.

John Stott mengatakan bahwa semua khotbah seharusnya menjadi khotbah ekspositori walaupun dia tidak menekankan khotbah ekspositori. Sedangkan menurut D.W. Lee diperlukan lima unsur supaya suatu khotbah dapat disebut sebagai khotbah Ekspositori, yaitu: Pertama, harus ada teks Alkitab. Kedua, arti asli teks itu dijelaskan. Ketiga, kebenaran secara umum yang ada di dalam teks dinyatakan. Keempat, kebenaran teks harus disusun dan dijelaskan dengan satu tema. Kelima, tema khotbah harus dijelaskan supaya tema itu diterapkan di dalam kehidupan jemaat. ${ }^{14}$

Keempat, Khotbah biografi, khotbah biografi adalah komunikasi ide atau gagasan yang diangkat dari kehidupan tokoh Alkitab, diamati dengan penafsiran yang benar, dikemas dalam bahasa kekinian, diterapkan oleh pengkhotbah dan pendengar, dan disampaikan dalam kuasa Roh Kudus. ${ }^{15}$ Khotbah biografi adalah suatu khotbah yang bertumpu pada tokoh karena tekanan utamanya

${ }^{14}$ D.W. Lee, Khotbah Ekspositori yang Membangunkan Pendengar (Bandung: Lembaga Literatur Baptis, 2002), 119-120.

${ }^{15}$ Noor Anggraito, Menyiapkan Khotbah Biografi Secara Praktis (Yogyakarta: Andi, 2009), 13. 
mencari keteladanan dan pelajaran dari tokoh yang dimaksud. Sumber utama khotbah biografi biasanya bersifat ekspositori dari Alkitab. Tokoh sentral khotbah biografi adalah tokoh dari Alkitab. Pengkhotbah yang alkitabiah tidak mungkin mengkhotbahkan seorang tokoh di luar Alkitab sebagai sumber utama khotbah, sekalipun mungkin orang tersebut berjasa dalam dunia kekristenan. ${ }^{16}$

Ada berbagai bentuk khotbah yang dapat dipilih oleh pengkhotbah, apa pun bentuknya suatu khotbah memerlukan struktur. Bentuk yang dipilih memerlukan persiapan, perencanaan dan penyajian yang baik. Khotbah tanpa struktur ibarat seperti rumah yang dibangun tanpa desain bukan hanya berpengaruh pada nilai-nilai estetikanya, tetapi bisa berpengaruh pada kekuatan rumah tersebut.

\section{PERANAN ROH KuduS DALAM BERKHOTBAH}

Ketika khotbah disampaikan kata-kata yang keluar dari seorang pengkhotbah bukan sekedar keterampilan dan kefasihan manusia semata. Kalau itu dipahami sekedar keterampilan dan kefasihan seorang manusia dapat dipastikan kata-kata yang disampaikan hanya sekedar keinginan manusia semata, belum tentu menjadi kehendak Allah. Kehendak Allah sudah jelas dinyatakan dan dituliskan dalam Alkitab. Alkitab adalah firman Tuhan, kebenaran dan kehendak-Nya dinyatakan dalam Alkitab, karena Alkitab adalah penyataan Allah kepada umat-Nya.

Di manakah peran Roh Kudus saat seorang pengkhotbah itu menyampaikan firman Tuhan? Apakah peran Roh terjadi pada saat seseorang berdiri dihadapan jemaat dan Roh Kudus menuntun seseorang pengkhotbah. Tidakkah Roh Kudus sudah bekerja dari sejak awal ketika seorang pengkhotbah mulai mencari dan membaca

16 Ibid, 4. 
nas Alkitab? Berikut akan diuraikan peran Roh Kudus dalam pelayanan berkhotbah:

\section{Roh Kudus Memimpin Seorang Pengkhotbah pada Saat Membaca Firman Tuhan}

Karya Roh Kudus bisa membimbing orang percaya atau seorang pengkhotbah pada saat membaca firman Tuhan. Yesus mendeklarasikan bahwa pada waktu Roh Kudus datang, Ia akan membimbing mereka pada semua kebenaran (Yohanes 16:13). Gambarannya seperti seorang pemandu atau pemimpin perjalanan menuju pada wilayah asing bagi mereka yang sedang melakukan perjalanan, tetapi dikenal oleh pemandu itu. ${ }^{17}$ Di kalangan ahli homiletik sebagian berpendapat bahwa ide khotbah muncul lebih dulu sebelum seorang pengkhotbah memilih teks Alkitab. Menurut mereka diakui atau tidak diakui, ide khotbah sudah lahir dalam pikiran seorang pengkhotbah sebelum ia memilih teks Alkitab yang dikhotbahkan. Sebaliknya yang lain berpendapat bahwa memilih teks seharusnya terjadi lebih dahulu sebelum seorang pengkhotbah mempunyai ide khotbah. Seorang pengkhotbah perlu mendisiplin dirinya untuk tidak membiarkan ide khotbahnya terbawa masuk ke dalam teks. Karena itu urutan diperlukan untuk menjaga kemurnian berita yang disampaikannya.

Pada praktiknya, penyusunan khotbah bisa dimulai dengan kedua pendekatan teersebut. Masalah yang penting adalah bagaimana pengkhotbah menafsirkan teks yang diambilnya itu, apakah ia mendapatkan amanat teks sesuai dengan maksud penulisnya. Memilih nas khotbah seharusnya tidak menjadi satu persoalan karena nas khotbah tidak bergantung pada panjang pendeknya teks Alkitab. Seorang pengkhotbah mengambil teks berupa satu ayat, satu paragrap, satu perikop, satu pasal, satu kitab penuh sekalipun. Pertimbangan yang penting adalah apakah teks tersebut merupakan satu unit pikiran.

17 Paul Enns, The Moody Handbook Of Theology, Jilid 1 (Malang: Literatur SAAT, 2003), 304. 
Kesadaran akan karya Roh Kudus itu yang seharusnya menuntun pengkhotbah untuk melakukan cara-cara memilih nas Alkitab seperti berikut:

a. Berdoa mohon bimbingan dari Roh Kudus. Hubungan pengkhotbah dengan Tuhan akan menemukan kepekaan kehendak-Nya.

b. Menyelidiki nas yang sudah dipilih. Hubungan pengkhotbah dengan pengalaman akan menghidupkan pemberitaannya.

c. Merenungkan apa yang menjadi kebutuhan pendengar. Hubungan pengkhotbah dengan sesama akan menjadikan khotbah bisa relevan dengan pendengar.

d. Mencari sesuai dengan tema yang diminta (apabila tema sudah ditentukan oleh gereja atau undangan). Hubungan antara pengkhotbah dengan perkembangan zaman, membuat khotbahnya akan akurat.

\section{Roh Kudus Menerangi Seorang Pengkhotbah pada Saat Membaca firman Tuhan}

Roh Kudus menerangi seorang Pengkhotbah untuk melihat kebenaran rohani. Dalam konteks ini, Roh Kudus dapat bertindak sebagai guru yang mengajarkan kebenaran rohani. Orang yang belum menerima keselamatan di dalam Kristus tidak dapat memahami kebenaran rohani. Apabila seseorang sudah bertobat, Roh Kudus yang mendiami orang percaya akan menjadi Penolong untuk mengajar atau menerangi sehingga orang tersebut mengerti kebenaran rohani. ${ }^{18}$

Roh Kudus menerangi orang-orang percaya itu juga yang dijanjikan Yesus ketika mengatakan: "Tetapi apabila Ia datang, yaitu Roh Kebenaran, Ia akan memimpin kamu ke dalam seluruh

${ }^{18}$ L. Towns, The Names of The Holy Spirit (Yogyakarta: Penerbit Andi, 2009), 21. 
kebenaran; sebab Ia tidak akan berkata-kata dari diri-Nya sendiri, tetapi segala sesuatu yang didengar-Nya itulah yang akan dikatakanNya dan Ia akan memberitakan kepadamu hal-hal yang akan datang." (Yohanes 16: 13). Sekalipun teks Alkitab itu dibaca berulang-ulang kalau Roh Kudus tidak menerangi seorang pengkhotbah ia tidak akan memahami kebenaran firman Tuhan. Itulah sebabnya Paulus mendoakan jemaat di Efesus supaya mereka mempunyai Roh hikmat dan wahyu serta mempunyai mata hati yang terang untuk mengerti betapa kayanya kemuliaan yang ditentukannya bagi orang-orang kudus (Efesus 1:17-18).

\section{Roh Kudus Menerangi Pengkhotbah Saat Menafsirkan Teks Alkitab}

Khotbah merupakan mekanisme jembatan yang menghubungkan dunia kuno dari teks Alkitab dengan dunia modern dari jemaat. Proses berkhotbah merupakan suatu upaya untuk menjembantani yang berkelanjutan, yang melalui seorang pengkhotbah menolong pendengar untuk menghidupi kembali drama dan kuasa rohani dari teks tersebut bagi pendengar aslinya dan kemudian memahami bagaimana pesan asli itu berkaitan dengan situasi yang serupa di dalam kehidupan mereka. Sebagaimana Roh Kudus berada dibalik kitab-kitab yang di dalam Alkitab (2 Tim. 3:16; 2 Petrus 1:21), demikian juga Roh Kudus pada dasarnya bisa menuntun dan menerangi pengkhotbah saat menafsirkan teks Alkitab. Hanya Roh Kudus yang dapat menguatkan pengkhotbah agar pesannya dijelaskan bukan dengan kata-kata yang menyakinkan berdasarkan hikmat manusia, tetapi lebih memerlihatkan "Roh Kudus" dan "Kuasa Allah" (1 Korintus 2:4-5). ${ }^{19}$

Klooster menggunakan istilah "iluminasi organik" untuk melukiskan hubungan Roh dengan proses penafsiran. Ini berarti Roh Kudus bekerja melalui pemikiran dan studi penafsir. Meskipun tidak jaminan bahwa orang tersebut akan "secara otomatis" mengerti makna yang dimaksud perikop itu. Dalam aspek demikian Roh

${ }^{19}$ Grant R. Osborne, The Hermeneutical Spiral: A Comprehensive Introduction to Biblical Interpretation, 527-529. 
Kudus menyediakan sarana-sarana hermeneutika semua menyediakan jalan bagi kehendak Roh dalam tindakan penafsiran. ${ }^{20}$

\section{Roh Kudus Menuntun Seorang Pengkhotbah pada Saat Menuliskan Teks Khotbah}

Karya Roh Kudus bukan hanya bekerja dan menolong pengkhotbah pada saat berkhotbah, tetapi sejak awal ketika pengkhotbah membaca Alkitab, Roh Kudus sudah menuntun dan menerangi seorang hambanya. Demikian juga ketika pengkhotbah mau menuliskan teks khotbah ia bukan semata-mata kepandaian intelektual manusia, tetapi Roh Kudus memberikan hikmat dan pengertian tentang kebenaran-kebenaran yang akan disampaikan oleh para pendengar.

Dalam ilmu homiletika ada beberapa teori bagaimana pengkhotbah itu menyampaikan firman Tuhan. Ada pengkhotbah yang menggunakan teks khotbah lengkap, ada yang berkhotbah dengan menggunakan teks khotbah ringkasan (garis besar khotbah beserta poin-poin kecilnya), sedang yang lain ada yang berkhotbah tanpa catatan apa pun. Sekalipun demikian penulis berpendapat bahwa cara berkhotbah dengan menggunakan ringkasan garis besar khotbah merupakan cara yang menolong karena pengkhotbah tidak terjebak pada teks khotbah yang kaku, sebaliknya memungkinkan terjadinya komunikasi yang hidup dengan pendengar.

Garis besar khotbah dibentuk supaya khotbah dapat dikomunikasikan secara efektif. Garis besar khotbah berbeda dengan naskah khotbah. Naskah khotbah biasanya meliputi semua hal yang akan disampaikan seorang pengkhotbah selama penyampaian khotbah. Garis besar khotbah mengandung pikiran-pikiran sebagai arahan untuk khotbah, tetapi juga memungkinkan kebebasan dari

${ }^{20}$ Ibid, 530. 
segi berkomunikasi. Garis besar khotbah berfungsi untuk mengarahkan khotbah dengan bebas, tetapi penyampaian khotbah dari naskah mengharapkan perkataan naskah itu dipakai kata perkata.

\section{Roh Kudus Memampukan Pengkhotbah pada Saat Menyampaikan Firman Tuhan}

Karya Roh Kudus sudah bekerja sejak seorang pengkhotbah menggumuli teks atau nas mana yang akan disampaikan kepada jemaat. Roh Kudus juga berkarya untuk menerangi hamba-Nya sehingga mengerti kebenaran firman Allah yang dituliskan di dalam Alkitab. Demikian juga ketika hamba-Nya mau menuliskkan teks khotbah, Roh Kudus menuntun hamba-Nya sehingga apa yang dicatat bukan karena kepandaian seorang pengkhotbah semata-mat.

Sebagaimana Roh Kudus bekerja dari sejak awal ketika pengkhotbah menggumuli tentang kebenaran firman-Nya, demikian juga ketika pengkhotbah berdiri di depan jemaat, Roh Kudus akan memampukan hamba-Nya sehingga firman Tuhan dapat diberitakan. Seperti yang dikatakan oleh Greg Schart: "kita yang berkhotbah diingatkan bahwa Roh Kuduslah yang memampukan kita berkhotbah, dan bahwa pekerjaan-Nya adalah memakai apa yang diilhamkan oleh-Nya dalam Alkitab dan menolong kita memahami Injil yang ada di dalamnya."21

Sama seperti Petrus ketika berkhotbah di depan banyak orang Yahudi (Kisah 2:14-40), Petrus bisa menyampaikan kebenaran firman Tuhan dengan lancar dan berani. Kemampuan Petrus berkhotbah di depan orang banyak bukan semata-mata karena kepandaian sebagai manusia, tetapi karena kuasa Roh Kudus yang memampukannya. Kondisi yang demikian berbanding kontras ketika Yesus ditangkap oleh para pemimpin agama dan dihadapkan ke Makamah Agama, Petrus menjadi seorang penakut dan tidak berani mengakui sebagai murid Kristus.

Keberanian Petrus dalam menyampaikan khotbah pada hari Pentakosta dipakai oleh Allah untuk mentobatkan 3000 orang.

${ }^{21}$ Greg Schart, Khotbah yang Transformatif (Jakarta: Yayasan Komunikasi Bina Kasih, 2013), 88-89. 
Bagaimanapun, kunci keberhasilan para rasul, termasuk Petrus bukan terletak pada kemampuan dan kekuatan mereka. Itulah peranan Roh Kudus yang memberikan kuasa kepada pengkhotbah pada saat ia menyampaikan khotbah. "Tetapi kamu akan menerima kuasa, kalau Roh Kudus turun ke atas kamu, dan kamu akan menjadi saksi-Ku di Yerusalem dan di seluruh Yudea dan Samaria dan sampai ke ujung bumi" (Kisah 1:8). Kemampuan yang diberikan oleh Roh Kudus membuat mereka dapat melakukan tugas dengan berhasil, dan kemampuan tersebut merupakan sumber kekuatan yang masih tersedia bagi pengkhotbah masa kini yang terpanggil untuk melayani Tuhan. ${ }^{22}$

\section{PENUTUP}

Pengkhotbah dan pribadi Roh Kudus mempunyai peran penting dalam pelayanan pemberitaan firman. Seorang pengkhotbah tidak hanya memenuhi kemampuan intelektual saja, tetapi kehidupan rohani, moral dan kepribadiannya merupakan kualifikasi yang harus melekat pada pribadi pengkhotbah. Para pendengar bukan hanya memerhatikan apa yang diucapkan seorang pengkhotbah, mereka juga memerhatikan apakah yang diucapkan sesuai dengan kelakuannya. Kehidupan seorang pengkhotbah seharusnya satu kata dan satu perbuatan.

Sekalipun tidak ada satu bentuk khotbah yang baku, namun bukan berarti sebuah khotbah disampaikan tanpa format atau bentuk yang tidak jelas. Khotbah sebaiknya menggunakan struktur atau sistematika yang baik. Tanpa struktur yang logis dan jelas, suatu khotbah tidak berkuatan sebagaimana mestinya. Bahkan tidak menutup kemungkinan tanpa struktur khotbah yang baik dapat menimbulkan kebingungan pendengar. Untuk menghindari

22 Millard J. Erickson, Teologi Kristen, Volume Tiga (Malang: Gandum Mas, 2004), 51-52. 
kebingungan tersebut, pengkhotbah harus memahami dan memerlukan struktur khotbah yang baik.

Di manakah peranan Roh Kudus saat seorang pengkhotbah itu menyampaikan firman Tuhan? Karya Roh Kudus akan membimbing pengkhotbah pada saat membaca firman Tuhan. Yesus mendeklarasikan bahwa pada waktu Roh Kudus datang, Ia akan membimbing mereka pada semua kebenaran. Roh Kudus menerangi seorang Pengkhotbah untuk melihat kebenaran rohani. Dalam konteks ini, Roh Kudus dapat bertindak sebagai guru yang mengajarkan kebenaran rohani. Roh Kudus bisa bekerja melalui pemikiran dan studi penafsir. Meskipun tidak ada jaminan bahwa pengkhotbah akan "secara otomatis" mengerti makna yang dimaksud dalam suatu perikop teks. Dalam aspek demikian Roh Kudus menyediakan sarana-sarana hermeneutika dan proses ini bisa menyediakan jalan bagi kehendak Roh dalam tindakan penafsiran.

Karya Roh Kudus bukan hanya bekerja dan menolong pengkhotbah pada saat berkhotbah, tetapi sejak awal ketika pengkhotbah membaca Alkitab, Roh Kudus sudah menuntun dan menerangi seorang hambanya. Demikian juga ketika pengkhotbah mau menuliskan teks khotbah itu bukan semata-mata kepandaian intelektual manusia, tetapi Roh Kudus memberikan hikmat dan pengertian tentang kebenaran-kebenaran yang akan disampaikan oleh para pendengar. Jadi ketika pengkhotbah berdiri di depan jemaat, Roh Kudus akan memampukan hamba-Nya sehingga firman Tuhan dapat diberitakan sesuai dengan kehendakNya

SunARTO, S.TH, M.TH Menyelesaikan program Sarjana Muda Teologi di Sekolah Tinggi Teologi Injili Efrata (STTI Efrata) Sidoarjo, Sarjana Teologi dan Master of Art di Sekolah Tinggi Teologi Injili Abdi Allah (STT IAA) di Pacet Mojokerto. Magister Teologi diperoleh dari Sekolah Tinggi Baptis Indonesia (STBI) di Semarang. Sekarang melayani sebagai dosen dan Puket I bidang Akademik di STT SAPPI Ciranjang Cianjur. 